\title{
Biochemical and physiological responses of Cannabis sativa to an integrated plant nutrition system
}

\author{
Jose F. Da Cunha Leme Filho ${ }^{1}$ (i) ｜ Wade E. Thomason ${ }^{1} \quad$ | Gregory K. Evanylo ${ }^{1}$

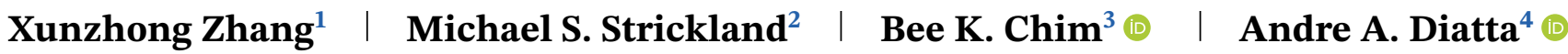

${ }^{1}$ School of Plant \& Environmental Sciences, Virginia Polytechnic Institute \& State University, 330 Smyth Hall, 185 Ag Quad Lane, Blacksburg, VA 24061, USA

2 Department of Soil and Water Systems, University of Idaho, 875 Perimeter Drive MS 2340, Moscow, ID 83844, USA

${ }^{3}$ United States Department of Agriculture - Agricultural Research Service, North Central Agriculture Research Lab, 2923 Medary Ave, Brookings, SD 57006, USA

${ }^{4}$ Department of Agronomy, Kansas State University, 2004 Throckmorton PSC, 1712 Claflin Road, Manhattan, KS 66506, USA

\section{Correspondence}

Jose Franco Da Cunha Leme Filho, School of Plant \& Environmental Sciences,

Virginia Polytechnic Institute \& State University, 330 Smyth Hall, 185 Ag Quad Lane, Blacksburg, VA 24061, USA.

Email:jfleme@vt.edu;

jfleme2@gmail.com

\begin{abstract}
The illegal status of cannabis (Cannabis sativa L.) post-World War II resulted in a lack of research on agricultural practices. However, there is a resurgence of interest in cannabis due to diverse uses such as a rich source of cellulosic/woody fiber and construction uses, seed oil, bioenergy and pharmaceutical properties. The principle of an integrated plant nutrition system (IPNS) is to enable adaptation of plant nutrition and soil fertility management to local site characteristics, attempting to optimize use of inorganic, organic and biological resources. This project investigated the individual and combined use of inorganic, organic and biological fertilizer resources on cannabis before and after a period of moderate water stress. We evaluated the individual and combined effects of commercial synthetic fertilizer, humic acid (HA), manure tea and bioinoculant as inorganic, organic and biological resources, respectively on cannabis growth and physiological parameters. Our hypothesis was that the synergetic effects of HA + biofertilizers would improve cannabis growth. When compared to the control, the application of HA and biofertilizer alone, or in combination, increased plant height, chlorophyll content and photosynthetic efficiency by 55,8 and $12 \%$, respectively, after water stress. Cannabis biomass of treated plants was rarely different from the control. The combined application of HA + biofertilizer resulted in additive, but not synergistic, increases in measured parameter. Future research should focus on the effects of biostimulants on $\mathrm{CBD} / \mathrm{THC}$ content due to the potential impact on the production of secondary metabolites in plants under stress.
\end{abstract}

\section{1 | INTRODUCTION}

Cannabis is classified into the family Cannabaceae and has three main types: C. sativa, C. indica, and C. ruderalis (Stearn, 1970) and has various prospective uses in the

Abbreviations: CBD, cannabidiol; HA, humic acid; IPNS, Integrated Plant Nutrition System; PE, post-emergence; THC,

9-tetrahydrocannabinol industrial, food and medical sector (Fike, 2016). However, after the Second World War cannabis cultivation decreased significantly (Callaway, 2004) and research, environmental impacts and legal human experience with this plant lost its importance (Eisenstein, 2015). According to Butsic and Brenner (2016) this lack of research on cannabis agricultural practices caused by the illegal status of the plant resulted in a lack of information related to water use, 
fertilizer and disease control requirement, cropping systems and yields.

Generally, cannabis agriculture has been underemphasized in terms of its potential to compete with other crops and, therefore, to become a regular source of income (Weisheit, 2011). However, hemp is receiving renewed interest due to its multi-purpose application as a rich source of cellulosic/woody fiber and construction uses (Andre, Hausman, \& Guerriero, 2016), seed oil (Kriese et al., 2004), bioenergy (Finnan \& Styles, 2013; Sausserde \& Adamovics, 2013) and pharmaceutical properties (Zuardi, 2006). Regarding the pharmaceutical utilization, there is expanding industry using cannabis extracts, specially cannabidiol (CBD), to minimize anxiety (Hagerty, Williams, Mittal, \& Hutchison, 2015), epileptic seizures (Detyniecki \& Hirsch, 2015; Rosenberg, Tsien, Whalley, \& Devinsky, 2015) and pain (Jensen, Chen, Furnish, \& Wallace, 2015). The cultivar 'Cherry Kandy' is a strain with high $\mathrm{CBD} / \mathrm{THC}$ ratio, mostly used for CBD extraction. Currently, there are a huge number of cannabinoids substances and the most abundant are cannabidiol (CBD), 9-tetrahydrocannabinol (THC), cannabigerol (CBG) and cannabichromene (CBC) (De Zeeuw, Malingre, \& Merkus, 1972; Holley, Hadley, \& Turner, 1975).

Some cannabis products are considered high value and the cultivation of this plant may be an alternative for small-scale farmers (Butsic \& Brenner, 2016) or those looking to improve profit per area. According to Werf (1994), cannabis can be a suitable crop for alternative agricultural practices such as organic agriculture, due to natural resistance to many pathogens and herbivores. However, cannabis is known to be susceptible to common diseases of other crops, such as Tobacco Mosaic Virus (Shivprasad et al., 1999). The popular belief is that cannabis as a relative low input crop (Seleiman, Santanen, Kleemola, Stoddard, \& Mäkelä, 2013) and adaptable to marginal soils, however several studies have shown that cannabis production requires adequate fertilizer supply to optimize yields (Adamovics, Ivanovs, \& Stramkale, 2016; Iványi, 2011). Therefore, the cannabis growers need an effective fertilization strategy to reach higher yields. According to the Food and Agriculture Organization of the United Nations (FAO) (Shand, 2007), the definition of an Integrated Plant Nutrition System (IPNS) is "the adaptation of the plant nutrition and soil fertility management in farming systems to site characteristics, taking advantage of the combined and harmonious use of inorganic, organic and biological nutrient resources to serve the concurrent needs of food production and economic, environmental and social viability".

Essential plant nutrients such as N, P and $\mathrm{K}$ from synthetic fertilizers are commonly used by conventional farmers, however there are other potential fertilizer products

\section{Core Idea}

- Cannabis height, chlorophyll and photosynthesis were affected by biofertilizer/humic acid.

- Cannabis biomass was rarely affected by the application of biofertilizer and/or humic acid.

- Not clear evidence found of additional benefits from the combined application of biofertilizer + HA.

- Biostimulants may contribute for cannabis stress mitigation.

originating from organic and biological sources. Humic acid (HA) compounds are categorized as an organic resource and there are many studies showing the effects of HA on plant development. El-Ghamry, El-Hai, and Ghoneem (2009) tested the application of different HA and amino acids on faba bean (Vicia faba L.) and found that the adequate rate significantly increased plant height, yield components, micronutrients adsorption and chlorophyll concentration. The proper HA rate also significantly increased root growth and nitrogen uptake of containergrown olive (Olea europea L.) plants (Tattini, Bertoni, Landi, \& Traversi, 1991). Studies addressing biofertilizer products originating from biological resources such as compost / manure teas and bioinoculants, have shown various benefits for plants. Wang, Radovich, Pant, and Cheng (2014) found that chicken manure-based vermicompost tea suppressed the abundance of plant-parasitic nematodes on zucchini (Cucurbita pepo L.) plants. Vermicompost extract stimulated seed germination, hypocotyl and radicle growth as well as increased chlorophyll content in cannabis (Ievinsh, Vikmane, Kirse, \& Karlsons, 2017). Conant, Walsh, Walsh, Bell, and Wallenstein (2017) tested a bioinoculant on cannabis and in addition to greater bud yield bioinoculant application also led to significant increases in plant height and basal steam area.

Plant biomass increase has been documented in response to the application of humic acid (Chen \& Aviad, 1990) and biofertilizers (Bashan \& de-Bashan, 2010; Pereg, de-Bashan, \& Bashan, 2016). According to Turner, Hemphill, and Mahlberg (1978), cannabinoid compounds are present in all aerial part of the cannabis plant, mainly in bracts and leaves. Thus, the utilization of this IPNS method with humic acid and biofertilizers can increase cannabis biomass and it might be beneficial for higher cannabinoid concentration on plants or even increment of fiber yield (Sausserde \& Adamovics, 2013) depending on the intention of each grower. Furthermore, in an online survey, Werse (2016) found that $43 \%$ of cannabis growers 
from Germany, Austria and Switzerland confirmed to have ecological ideology and/or activist reasons to grow cannabis. Therefore, cannabis growers might be willing to accept more environmentally friendly agricultural methods such as IPNS when compared to conventional farmers. Previous research demonstrating beneficial outcomes of the use of HA and biofertilizers on various plants and the inclination of cannabis growers to embrace more sustainable practices created the interest to conduct this study. Therefore, this study evaluated the effects of an IPNS with the combined and individual use of HA and manure tea and bioinoculants along with inorganic fertilizer on cannabis development including plant height, chlorophyll amount (atLEAF), photosynthetic efficiency and biomass under greenhouse condition. Our objectives were to access cannabis plant growth effects from the selected biostimulants and whether or not combining various types of biostimulants can result in a synergistic effect. We hypothesized that biostimulants will increase cannabis plant growth and that there would be synergetic effects of the combination of HA + biofertilizer on cannabis growth compared to each substance alone or the control.

\section{2 | MATERIALS AND METHODS}

In this greenhouse study, humic acid (HA) was used as an organic resource and manure tea and bioinoculants were used as biological resources along with conventional inorganic fertilizer resources (N, P, and $\mathrm{K}$ ) in an IPNS.

\section{1 | Products description}

Four products, including inorganic, organic and biological resources, were used in this study. The inorganic fertilizer was Osmocote Plus; the organic product was MicroLife Humic Acid Complex; and the biological products were Microgeo and Microgro Supreme Bioinoculant. Osmocote Plus (15-9-12) is a slow release synthetic fertilizer containing 11 essential nutrients for plants. The humic category was represented by MicroLife Humic Acid Complex which was constituted mainly by $15 \%$ humic acid and $1 \%$ fulvic acid. One of the two biological fertilizers was Microgeo which is a Brazilian patented product categorized as a manure tea. This biofertilizer is composed of organic compounds, active and dormant cells from various microorganisms (bacteria, yeasts, filamentous fungi, and algae), metabolites and organo-mineral chelates and it is produced through continuous anaerobic fermentation in a liquid media (D'andrea, 2002). According to the technical manual, the preparation uses the CLC (Continuous
Liquid Composting) process, where $5 \%$ of the commercial biological fertilizer Microgeo, $15 \%$ of ruminal content and $80 \%$ water are mixed in a tank at sunlight. After 15 days, the biofertilizer production is complete. The Microgro Supreme Bioinoculant is a water-soluble powder containing several strains of bacteria and fungi including 11 different Mycorrhizal species and microbial food (sugars, humic acid, kelp, amino acids and yeast extract). Products derived from humic acid and biological sources are broadly categorized as biostimulants. Products descriptions are summarized in Table 1.

\section{2 | Experimental design and management}

The experiment was conducted under controlled conditions in a greenhouse in Blacksburg, Virginia, USA to investigate the individual and combined effects of humic acid (HA), manure tea and bioinoculant application on cannabis (Cannabis sativa L.) cultivar 'Cherry Kandy' growth including plant height, chlorophyll amount, photosynthetic efficiency and biomass under greenhouse condition. Polyethylene pots $(19 \mathrm{~cm}$ tall, $19 \mathrm{~cm}$ outside diameter, $37,850 \mathrm{~cm}^{3}$ volume and $314 \mathrm{~cm}^{2}$ surface area) were lined with plastic bags to avoid water loss. Soil media and sand (50\% Metro-mix 360 and 50\% playground sand, respectively) were placed in a polyethylene pot $22 \mathrm{~g}$ of inorganic fertilizer (Osmocote Plus) was equally added to each pot, following the recommended application rate of $9.8 \mathrm{~kg} / 100 \mathrm{~m}^{2}$ and blended thoroughly with media by hand. According to the bulk density provided in the physical/chemical characteristics data sheet of each component, we added $0.425 \mathrm{~kg}$ Metro-mix 360 and $3 \mathrm{~kg}$ sand to each pot to have an equal volume. Separately, the cannabis feminized seeds were planted in a seedling transplant tray filled with soil media (Pro-mix general purpose) at $3 \mathrm{~cm}$ depth. Seedlings were transplanted to pots at 12 days postemergence at which time the growth stage was three true leaf pairs on the BBCH scale (Mishchenko et al., 2017).

There was a total of 9 treatments with each individual product applied at $1 \mathrm{x}$ and $2 \mathrm{x}$ the label rate (Table 2). The treatments combining biofertilizers + HA received only the label rate of each product (Table 2). The trial utilized a completely randomized design (CRD) with five replications. The application of each treatment occurred at cannabis growth stages 4, 6, 7 and 9 true leaf pairs (compound). The treatments were previously prepared in the laboratory and applied to each pot using an electronic pipette. Solid materials were dissolved in water and the appropriate rate applied to respective pots. According to the label of each product, the dilution rates were: Microgeo, $150 \mathrm{~L} / \mathrm{ha}$; Microgro Supreme, $6.1 \mathrm{~kg} /$ ha diluted in $233 \mathrm{~L}$ 
TA B LE 1 Product description and components

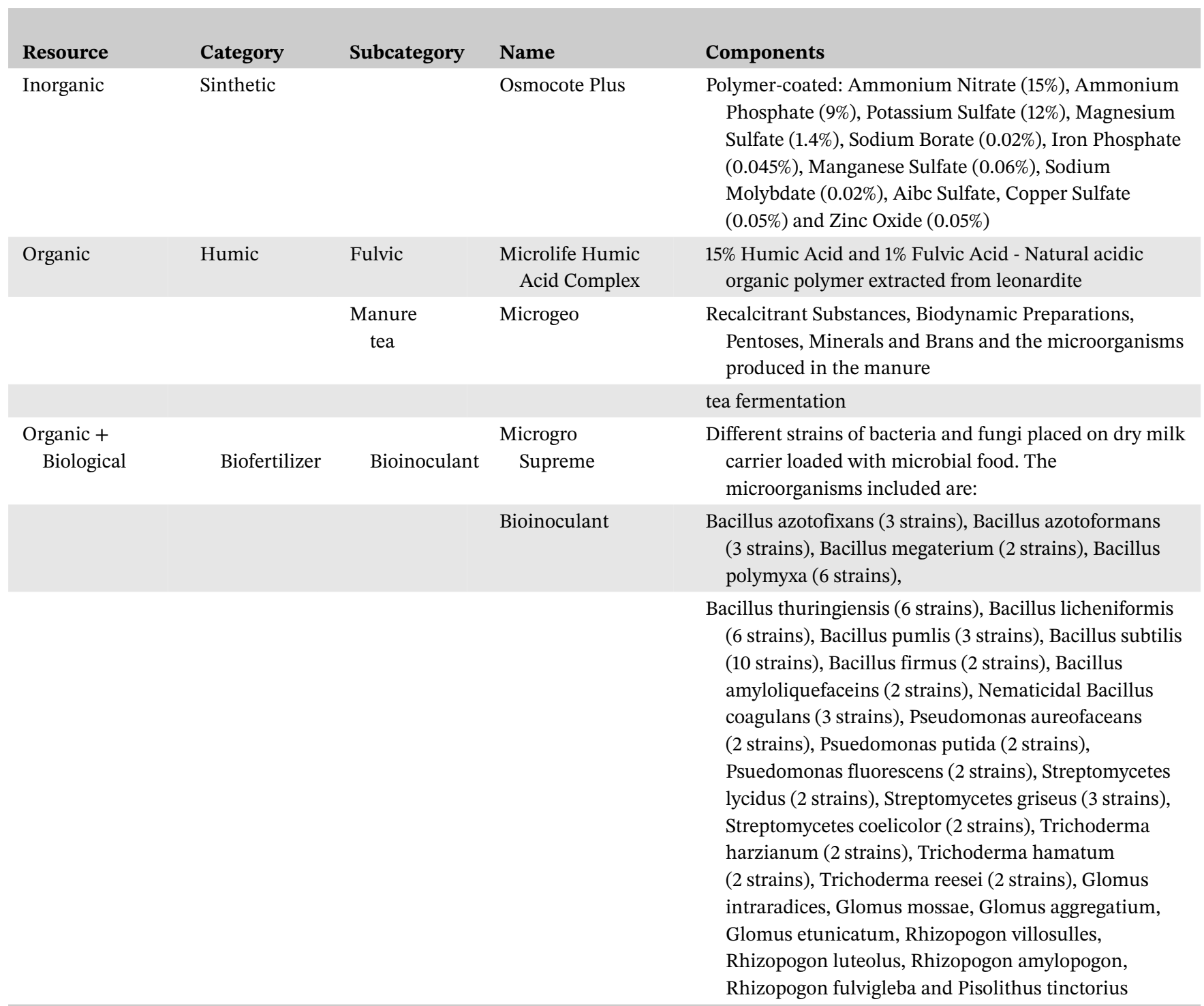

of water and Microlife Humic, $14 \mathrm{~L} /$ ha diluted in $233 \mathrm{~L}$ of water. The application of each treatment followed the dilution rate of the products and the proportions were properly adjusted according to the size of the pot.

\section{3 | Water regime and data collection}

The field capacity of the soil media + sand was determined by saturating the media until water was observed dripping from the bottom of the pot. One day later, the weight of the wetted pot was used to estimate field capacity threshold (Kirkham, 2014).

The pots were maintained at $60 \%$ field capacity during most of the experiment to ensure adequate moisture for cannabis growth. Between 35 and 42 days post-emergence
(PE), watering was reduced to $30 \%$ of field capacity to induce mild to moderate drought stress. The watering procedure was conducted manually using the gravimetric water content method and the water status checked each day. Plant height at the last shoot apex, atLEAF chlorophyll meter value (FT Green LLC, Wilmington, DE) and photosynthetic efficiency/OS-50II fluorometer (Opti-Sciences, Tyngsboro, MA) measurements were collected from the latest fully developed leaf at 33, 42 and 55 days PE. At 55 days $\mathrm{PE}$, aboveground plant material was clipped at the soil surface and dried at $70{ }^{\circ} \mathrm{C}$ until a constant weight was achieved, and plant dry matter yield calculated. Cannabis growth stages corresponding to 33,42 and 55 days postemergence were 7, 9 and 11 true leaf pairs (compound), respectively. Prior to sampling at 55 days $\mathrm{PE}$ (11 true leaf pairs) plants were still receiving applications. After 
TA B L E 2 Treatments and application rates

\begin{tabular}{|c|c|c|c|c|c|}
\hline \multirow[b]{2}{*}{ No. } & \multirow[b]{2}{*}{ Subcategory } & \multicolumn{4}{|l|}{ Treatments } \\
\hline & & $\begin{array}{l}\text { Product name and } \\
\text { abbreviation }\end{array}$ & Rate & Label & $\begin{array}{l}\text { Rate/pot (each } \\
\text { application) }\end{array}$ \\
\hline 2 & & Microgeo (M) & $2 \mathrm{x}$ & $150 \mathrm{~L} / \mathrm{ha}$ & $0.94 \mathrm{ml}$ \\
\hline 3 & & $\begin{array}{l}\text { Microgro Supreme } \\
\text { Bioinoculant (MB) }\end{array}$ & $1 \mathrm{x}$ & $6.1 \mathrm{~kg} / \mathrm{ha}$ & $19 \mathrm{mg}$ \\
\hline 5 & Humic & Microlife Humic (H) & $1 \mathrm{x}$ & $14 \mathrm{~L} / \mathrm{ha}$ & $0.043 \mathrm{ml}$ \\
\hline 6 & & Microlife Humic (H) & $2 \mathrm{x}$ & $14 \mathrm{~L} / \mathrm{ha}$ & $0.086 \mathrm{ml}$ \\
\hline 7 & $\begin{array}{l}\text { Humic }+ \\
\quad \text { Biofertilizer }\end{array}$ & $\begin{array}{c}\text { Microgeo + Microlife } \\
\text { Humic }(\mathrm{M}+\mathrm{H})\end{array}$ & $1 \mathrm{x}, 1 \mathrm{x}$ & $\begin{array}{l}150 \mathrm{~L} / \mathrm{ha} \text { and } \\
14 \mathrm{~L} / \mathrm{ha}\end{array}$ & $0.47 \mathrm{ml}+0.043 \mathrm{ml}$ \\
\hline 9 & & Control (C) & $0 x$ & 0 & 0 \\
\hline
\end{tabular}

aboveground biomass harvest, roots were separated from the soil media + sand by shaking and root dry matter calculated in a similar manner to the shoot.

\section{4 | Data analysis}

A univariate distribution for each variable was determined with outliers evaluated and removed when studentized residual was greater than 2.5. Statistical analyses were performed using the GLM procedure in SAS 9.4 (SAS Institute, Cary, NC, USA) with all variables except replication considered fixed effects. Treatment effects on plant height, atLEAF chlorophyll meter, photosynthetic efficiency, plant root and shoot, and total plant biomass were assessed. Mean separations were performed using the Tukey-Kramer command within the LSMEANS statement when F-tests indicated that significant differences existed $(p<.05)$.

\section{RESULTS AND DISCUSSION}

\subsection{Plant height}

In general, the biostimulants which include the treatments with biofertilizers, HA and the combination of both, referring to all the treatments of this study except control, produced taller plants at all three timings. Plant heights collected at 33 days PE and after the water stress period (42 days $\mathrm{PE}$ ) were more frequently greater than the control (Table 3) than at 55 days PE which had the fewest treatments that were different from the control (Table 3).

Cannabis sativa treated with Mammouth-P biofertilizer containing several beneficial bacteria culture grew significantly taller than the control and had a $16.5 \%$ increase in bud yield, mostly likely due its effects on plant height and basal stem area (Conant et al., 2017). Pagnani et al. (2018) reported that addition of plant growth-promoting rhizobacteria (PGPR) and nitrogen promoted significantly greater cannabis stem length compared to the control. These authors attributed differences among treatments to the density of bacteria in the solution. In this sense, the two biofertilizer rates tested in this current study could theoretically lead to a different density of bacteria applied in the pot but we measured no effect on plant height (Table 3). Studies have shown that the use of biofertilizers containing one or more beneficial microorganisms alleviate the imposed water stress in a greenhouse environment, increasing shoot and root growth of corn (Casanovas, Barassi, \& Sueldo, 2002) and asparagus (Asparagus officinalis L.) (Liddycoat, Greenberg, \& Wolyn, 2009). In our studies, the application of biofertilizers alone increased cannabis height compared to the control, mainly during the post water stress period measured at 42 days PE.

Humic acids are known to minimize drought stress effects. However, our data collected immediately following the water stress period (42 days PE), showed that only half of the treatments that received HA had significantly taller plants. When comparing all data collection periods, the treatments containing HA (alone and in combination) at 42 days PE were more frequently different from the control than at 55 days $\mathrm{PE}$ but less frequent than 33 days 
TA B L E 3 Effects of biostimulant treatments on cannabis plant height at 33, 42 and 55 days post-emergence (PE)

\begin{tabular}{|c|c|c|c|c|c|c|c|c|}
\hline \multirow{2}{*}{$\begin{array}{l}\text { Group } \\
\text { None }\end{array}$} & \multirow{2}{*}{$\begin{array}{l}\text { Category } \\
\text { None }\end{array}$} & \multirow{2}{*}{$\begin{array}{l}\text { Treatment } \\
\text { Control }\end{array}$} & \multirow{2}{*}{\multicolumn{2}{|c|}{$\frac{33 \text { days PE }}{\text { Plant height }}$}} & \multirow{2}{*}{\multicolumn{2}{|c|}{42 days $P E$}} & \multirow{2}{*}{\multicolumn{2}{|c|}{55 days $P E$}} \\
\hline & & & & & & & & \\
\hline \multirow[t]{5}{*}{ Biostimulant } & Biofertilizer & Microgeo (M) 1x & 24.9 & $\mathrm{a}$ & 35.6 & a & 51.3 & $a b$ \\
\hline & & Microgeo (M) 2x & 27.9 & a & 40.1 & a & 60.5 & a \\
\hline & Humic & Microlife Humic (H) 1x & 22.8 & $\mathrm{a}$ & 35.1 & $\mathrm{a}$ & 58.4 & $\mathrm{a}$ \\
\hline & & Microlife Humic (H) 2x & 22.4 & a & 33.5 & $\mathrm{ab}$ & 52.8 & $a b$ \\
\hline & $\begin{array}{l}\text { Humic }+ \\
\quad \text { Biofertilizer }\end{array}$ & $M+H$ & 23.9 & $\mathrm{a}$ & 34.5 & $\mathrm{a}$ & 47.2 & $a b$ \\
\hline
\end{tabular}

${ }^{\mathrm{a}}$ Means within a column followed by the same letter are not significantly different at the .05 probability level.

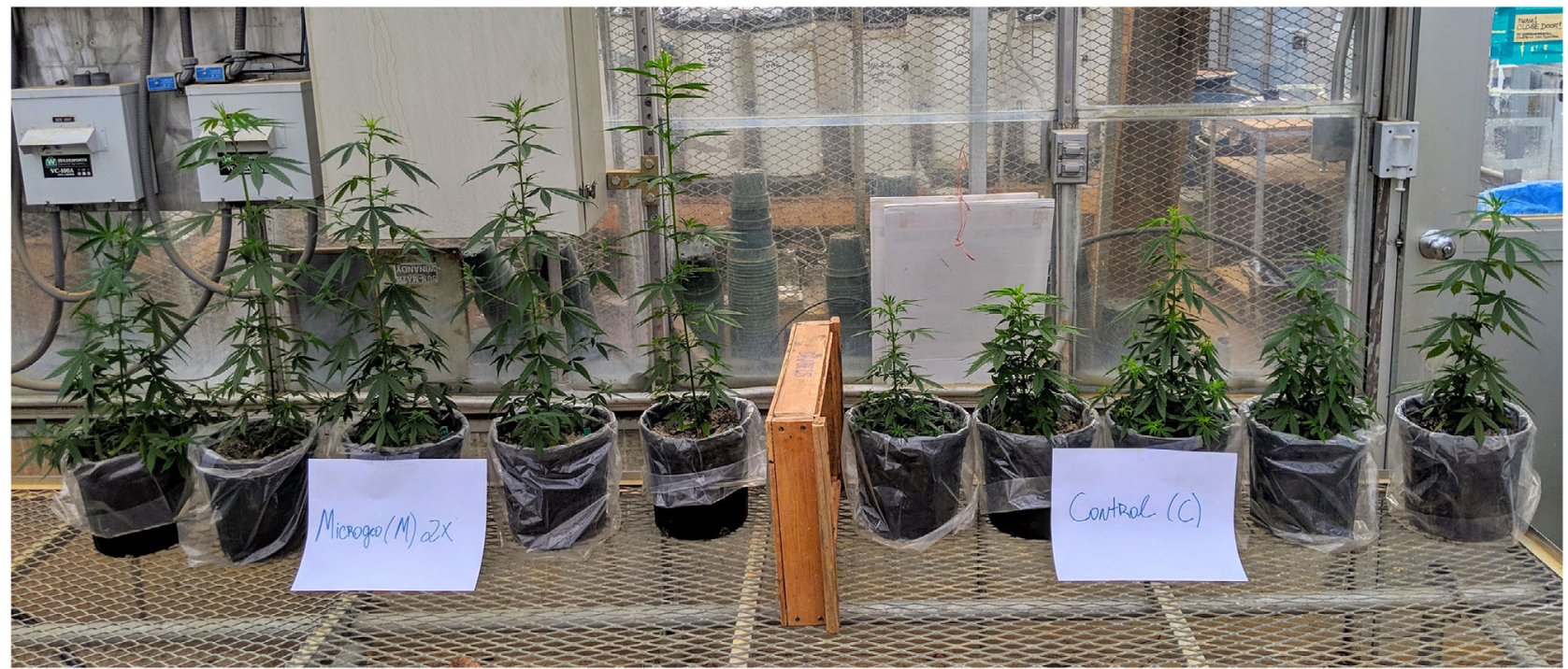

F I G U R E 1 Plant height visual contrast between Microgeo 2x treated plants (left) and control (right) at 55 days post-emergence

PE. Similar to what we observed with cannabis, application of HA increased growth of bluegrass (Poa pratensis L.) (Xungzhong Zhang \& Schmidt, 1999) and rice (Oryza sativa L. cv. IACUB-30) (García et al., 2012) under water stress conditions.

The biofertilizer + HA treated plants were not different in plant height from independent application of biofertilizers or HA at data collection periods (Figure 1).

\section{2 | Chlorophyll amount (atLEAF)}

The physiological status and stress conditions of plants are often accessed through non-destructive measures such as estimating chlorophyll content (Jaleel et al., 2009) and photosynthetic efficiency (Ruiz-Sánchez, Aroca, Muñoz,
Polón, \& Ruiz-Lozano, 2010). The atLEAF value provides an indirect estimation of the actual chlorophyll content of the leaves.

The atLEAF values for humic acid products were higher than the control at 33 and 42 days PE, while only the values for humic + biofertilizer were higher at 55 days PE (Table 4). While atLEAF values were inconsistently affected by treatment, only the two rates of Microlife Humic were not statistically greater than the control at 55 days PE. Similar to our work, cannabis plants fertilized with two different rates of a PGPR had significant higher SPAD (chlorophyll meter) values when comparing with the control (Pagnani et al., 2018). Russo and Berlyn (1991) also reported that HA + marine algae (MA) application on rye grass (Lolium perenne L.) yielded $74 \%$ more chlorophyll than the control. 
TA B L E 4 Effect of biostimulants treatments on cannabis atLEAF values collected at 33, 42 and 55 days post-emergence (PE)

\begin{tabular}{|c|c|c|c|c|c|c|c|c|}
\hline \multirow{2}{*}{$\begin{array}{l}\text { Group } \\
\text { None }\end{array}$} & \multirow{2}{*}{$\begin{array}{l}\text { Category } \\
\text { None }\end{array}$} & \multirow{2}{*}{$\begin{array}{l}\text { Treatment } \\
\text { Control }\end{array}$} & \multirow{2}{*}{\multicolumn{2}{|c|}{$\frac{33 \text { days } P E}{\text { atLEAF }}$}} & \multirow{2}{*}{\multicolumn{2}{|c|}{42 days $P E$}} & \multicolumn{2}{|c|}{55 days $P E$} \\
\hline & & & & & & & & \\
\hline \multirow[t]{5}{*}{ Biostimulant } & Biofertilizer & Microgeo (M) 1x & 0.0680 & $\mathrm{a}$ & 0.0718 & $\mathrm{ab}$ & 0.0725 & $a b c$ \\
\hline & & Microgeo (M) 2x & 0.0693 & $\mathrm{a}$ & 0.0698 & $a b c$ & 0.0728 & $a b$ \\
\hline & Humic & Microlife Humic (H) 1x & 0.0680 & $\mathrm{a}$ & 0.0672 & $\mathrm{bc}$ & 0.0677 & cde \\
\hline & & Microlife Humic (H) 2x & 0.0686 & $\mathrm{a}$ & 0.0653 & c & 0.0674 & de \\
\hline & $\begin{array}{l}\text { Humic }+ \\
\quad \text { Biofertilizer }\end{array}$ & $\mathrm{M}+\mathrm{H}$ & 0.0749 & $\mathrm{a}$ & 0.0740 & $\mathrm{a}$ & 0.0758 & $\mathrm{a}$ \\
\hline
\end{tabular}

${ }^{a}$ Means within a column followed by the same letter are not significantly different at the .05 probability level.

TA B L E 5 Effect of biostimulant treatments on cannabis photosynthetic efficiency values collected at 33, 42 and 55 days post-emergence (PE)

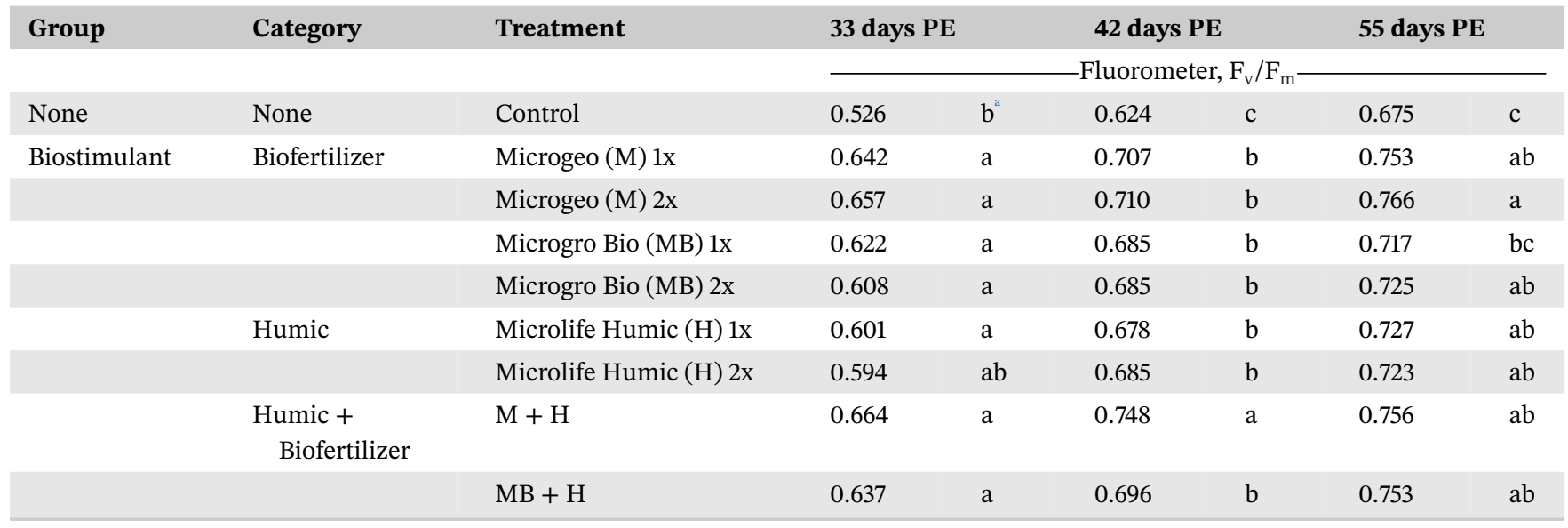

${ }^{a}$ Means within a column followed the same letter by sites are not significantly different at the 0.05 probability level.

The atLEAF values for treatments combining Humic + Biofertilizers were greater than the control, however they were statistical similar to the treatments receiving only HA or biofertilizer. Following the analogous approach of biofertilizer + HA integration, Ferrini and Nicese (2002) assessed the influence of two commercial biostimulants products on English oak (Quercus robur L.). Both products containing HA and different types of biofertilizers had greater SPAD values in two consecutive years in comparison to control (no biostimulant).

The atLEAF readings collected at 42 days $P E$ (post water stress) likely indicate that biostimulants increased chlorophyll content relative to the control (Table 4). The HA are natural soil constituents and can positively affect water retention due their high exchange capacity (Kelting, 1997). Biofertilizers are also known to mitigate water stress of several plants (Berruti, Lumini, Balestrini, \& Bianciotto, 2016; Ruiz-Lozano \& Azcón, 1995). Considering that water stress reduced chlorophyll content in many studies and that biostimulant application generally maintained greater atLEAF readings that the control in this study, it might infer another effect of these compounds.

\section{3 | Photosynthetic efficiency $\left(F_{v} / F_{m}\right)$}

Photosynthesis-related parameters were measured to test physiological responses of cannabis plants to additional input of biofertilizers and/or HA. According to Chandra (2003), the ability of plants to be successfully resilient in different environments, including under stress conditions, is associated with an ability to maintain high photosynthetic efficiency.

At 42 and 55 days PE was consistently greater in treatments receiving biostimulants in comparison to control values (Table 5), as was the case with atLEAF readings 
(Table 4). According to Jat and Ahlawat (2006), inoculation with biofertilizers such as Rhizobium, can increase the development of photosynthetic organs in plants and consequently maximize the accumulation of photosynthates. Veres et al. (2009) specifically addressed the changes of photosynthetic efficiency $\left(\mathrm{F}_{\mathrm{v}} / \mathrm{F}_{\mathrm{m}}\right)$ under biofertilizer application and found that $\mathrm{F}_{\mathrm{v}} / \mathrm{F}_{\mathrm{m}}$ was higher in the treatments containing reduced $\mathrm{N}$ supply + biofertilizer. Thus, the use of biofertilizer could compensate for the $\mathrm{N}$ deficiency. The photosynthetic efficiency was also significantly higher on passion fruit (Passiflora edulis) tested with biofertilizers derived from cattle manure (de Oliveira Freire, Dias, Cavalcante, Fernandes, \& Lima Neto, 2014).

Like the biofertilizer treatments, PE values for the two application rates of HA and the combination with biofertilizers were generally greater than the control but very few differences existed among them. The application of HA alone and in combination with seaweed extract (SWE) was tested on creeping bentgrass (Agrostis stolonifera L.) during two years (Xunzhong Zhang, Ervin, \& Schmidt, 2003a). In the first year, they found $18 \%$ and $15 \%$ increases in $\mathrm{F}_{\mathrm{v}} / \mathrm{F}_{\mathrm{m}}$ values, when HA or HA + SWE were applied, respectively. In the second year, the $\mathrm{F}_{\mathrm{v}} / \mathrm{F}_{\mathrm{m}}$ values increased by $11 \%$ and $12 \%$, respectively. A foliar application of HA + SWE also significantly increased $F_{v} / F_{m}$ values on fieldgrown tall fescue (Festuca arundinacea Scheb.) (Xunzhong Zhang, Ervin, \& Schmidt, 2003b). Interestingly, the presence of $\mathrm{HA}$ prevented the reduction of $\mathrm{F}_{\mathrm{v}} / \mathrm{F}_{\mathrm{m}}$ values in duckweed (Lemna gibba L.) exposed to anthracene photoinduced toxicity (Gensemer, Dixon, \& Greenberg, 1999). In fact, photosystem II (PSII) is anthracene's site of action (Huang, McConkey, Babu, \& Greenberg, 1997) and PE is a measurement of PSII activity (Oxborough \& Baker, 1997).

Shortly after drought stress was imposed (42 days PE) we observed that $F_{v} / F_{m}$ values were greater than the control for all biostimulants treatments (Table 5). According to Richmond (1999), photosynthesis is the first plant physiological attribute to react to stress. There are a vast number of studies where the use of biofertilizers and/or HA improved photosynthetic efficiency values on plants under stress (Hassanpanah, 2009; Lotfi, Gharavi-Kouchebagh, \& Khoshvaghti, 2015).

Water stress can increase secondary metabolites (Gorelick \& Bernstein, 2014). Secondary metabolites are linked with the production of cannabinoids which can affect final yield of CBD or THC depending on the goals of the producer. Therefore, if the objective is to increase CBD or THC production, exposing cannabis plants to stress might be considered beneficial and the application of products reducing stress could harm CBD or THC production. There is evidence that moisture stress is linked with higher tetrahydrocannabinol content (THC) on cannabis (Paris, Boucher, \& Cosson, 1975). A similar phenomenon was reported by Murari, Puccini, Sanctis, and Lombardi (1983), where drier continental environments promoted the production of THC in cannabis plants naturally lacking in THC. Sharma (1975) reported a positive correlation between trichome density and low humidity environments in cannabis plants. Trichomes are important sites of CBD storage (Mahlberg \& Kim, 2004), so this could affect final CBD yield.

Mechanistic evidence of how biofertilizers, HA and the combination of both sources maximize photosynthetic efficiency or even chlorophyll content is still developing. However, we speculate that the hormonal-like effects and antioxidant status of these compounds might have a causative role, especially under stress. External input of man-made hormone substances such as Indole-3-acetic acid (IAA) (Aldesuquy, 2000) and cytokinin (Noodén \& Leopold, 2012) has increased photosynthetic rates. Vessey (2003) mentioned the presence of phytohormones or the precursor of hormones in many biofertilizers, including IAA produced by PGPR (Barazani \& Friedman, 1999). It is unclear whether HA liberates locked hormonal compounds (chelating capability) or stimulates the production of hormones by microorganisms (du Jardin, 2012). As mentioned above there are studies reporting that plants exposed to stress will increase the production of secondary metabolites and potentially CBD or THC, so the use of biostimulants that minimize stress would decrease the production of these cannabinoids. There are also studies showing that biofertilizers and HA stimulate plant hormone production and consequently higher secondary metabolites, which is linked to greater cannabinoid concentration in plants. The application of biostimulants on cannabinoid concentration could be either positive or negative. More studies specifically addressing the effects of these biostimulants on cannabinoids would help to identify the pros and cons of biofertilizer and HA on CBD and THC production.

\section{4 | Shoot, root and total biomass}

Generally, shoot, root and total biomass at the end of the experimental period were similar between biostimulant treatments and the control (Table 6). Previous research has also reported that application of AMF and PGPR biofertilizer to cannabis plants did not increase shoot biomass compared to the uninoculated treatments (Gryndler et al., 2008). The less frequent increased cannabis biomass growth in response to biofertilizer application in our study might be due a plant etiolation, thus the biofertilizers promoted taller plants but biomass did not follow the same trend. Also, the biofertilizer effects on cannabis height were more evident in the two earlier data collection periods ( 33 and 42 days $\mathrm{PE}$ ), then at 55 days $\mathrm{PE}$, the height 
TA B L E 6 Effects of biostimulant treatments on cannabis shoot, root and total biomass values collected at 55 days post-emergence (PE)

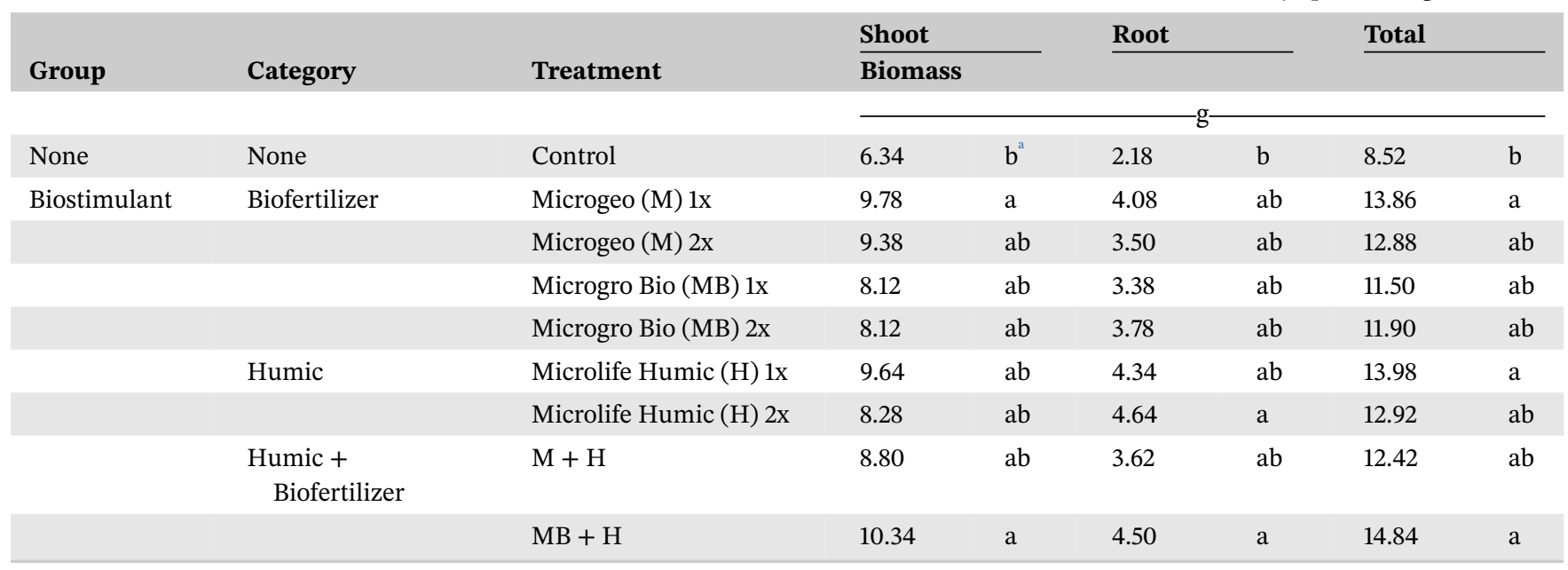

${ }^{\mathrm{a}}$ Means within a column followed by the same letter are not significantly different at the .05 probability level.

values were more similar to control which may explain fewer statistically significant values of biomass. Studies have tested the effectiveness of biofertilizers containing different strains of microorganism and the responses are variable depending on the active strains, harvest date, environment and growth parameter evaluated (Germida \& Walley, 1996; Requena, Jimenez, Toro, \& Barea, 1997).

Only the application of Microgro Bio + Microlife Humic $(\mathrm{MB}+\mathrm{H})$ consistently produced greater shoot, root and consequently total biomass than the control (Table 6). Olivares, Aguiar, Rosa, and Canellas (2015) reported that the combined use of biofertilizer + HA promoted greater tomato (Solanum lycopersicum L.) shoot, root and fruit biomass compared to either product applied alone. However, in our study only one of two treatments combining biofertilizer + HA had greater biomass than the control. Plant biomass in response to Microgeo + Microlife Humic $(\mathrm{M}+\mathrm{H})$ did not differ from control.

\section{4 | CONCLUSIONS}

Application of biofertilizer and HA alone, or in combination, generally increased cannabis plant height, chlorophyll content and photosynthetic efficiency, especially immediately after a period of water stress (42 days PE). Cannabis biomass was generally not different from the control. However, total plant biomass at 55 days PE was greater than the control for application of Microgeo $1 \mathrm{x}$, Microlife Humic $1 \mathrm{x}$ and 2x and Microgro Bioinoculant + Microlife Humic. Applying twice the labeled rate generally did not result in differences from the recommended rate. A range of rates would need to be tested in order to validate that the label rate is in fact the most appropriated application rate. Similarly, this study was not designed to be a test of all possible biostimulants products or even one within a single class, but to assess the impacts of the selected products as representatives of their various classes. There was not clear evidence of additional benefits from the combined application of biofertilizer + HA. However, the potential biostimulant effects of these compounds that improve cannabis stress tolerance could prove important as it could impact CBD content. Further studies addressing the entire cannabis cycle should be conducted to validate these findings and confirm if these plant biostimulant effects extend to the end of the cannabis season. Moreover, the next step for this research would be testing the effects of these biostmulants and stress conditions on $\mathrm{CBD} / \mathrm{THC}$ content.

\section{ACKNOWLEDGMENTS}

This research was made possible by the contributions of the School of Plant \& Environmental Sciences at Virginia Polytechnic Institute \& State University.

\section{CONFLICT OF INTEREST}

The authors declare that they have no conflict of interest.

\section{O R C I D}

Jose F. Da Cunha Leme Filho (10 https://orcid.org/00000002-4192-5945

Bee K. Chim (10) https://orcid.org/0000-0002-2169-967X Andre A. Diatta (1) https://orcid.org/0000-0003-4720-9760

\section{REFERENCES}

Adamovics, A., Ivanovs, S., \& Stramkale, V. (2016). Investigations about the impact of norms of the fertilizers and cultivars upon the crop capacity biomass of industrial hemp. Agronomy Research, 14(3), 641-649.

Aldesuquy, H. (2000). Effect of indol-3-yl acetic acid on photosynthetic characteristics of wheat flag leaf during grain filling. Photosynthetica, 38(1), 135-141. 
Andre, C. M., Hausman, J.-F., \& Guerriero, G. (2016). Cannabis sativa: The plant of the thousand and one molecules. Frontiers in Plant Science, 7, 19-19. https://doi.org/10.3389/fpls.2016.00019

Barazani, O., \& Friedman, J. (1999). Is IAA the major root growth factor secreted from plant-growth-mediating bacteria? Journal of Chemical Ecology, 25(10), 2397-2406.

Bashan, Y., \& de-Bashan, L. E. (2010). How the plant growthpromoting bacterium Azospirillum promotes plant growth: A critical assessment. In D. L. Sparks (Ed.), Advances in agronomy (Vol. 108, pp. 77-136). New York: Academic Press.

Berruti, A., Lumini, E., Balestrini, R., \& Bianciotto, V. (2016). Arbuscular mycorrhizal fungi as natural biofertilizers: Let's benefit from past successes. Frontiers in Microbiology, 6, 1559.

Butsic, V., \& Brenner, J. C. (2016). Cannabis (Cannabis sativa or $C$. indica) agriculture and the environment: A systematic, spatiallyexplicit survey and potential impacts. Environmental Research Letters, 11(4), 044023.

Callaway, J. C. (2004). Hempseed as a nutritional resource: An overview. Euphytica, 140(1), 65-72. https://doi.org/10.1007/s10681004-4811-6

Casanovas, E. M., Barassi, C. A., \& Sueldo, R. J. (2002). Azospirillum inoculation mitigates water stress effects in maize seedlings. Cereal Research Communications, 2002, 343-350.

Chandra, S. (2003). Effect of leaf age on transpiration and energy budget in Ficus glomerata Roxb. Physiology and Molecular Biology of Plants, 9, 255-260.

Chen, Y., \& Aviad, T. (1990). Effects of humic substances on plant growth. In P. MacCarthy, C. E. Clapp, R. L. Malcolm, \& P. R. Bloom (Eds.), Humic substances in soil and crop sciences: Selected readings (pp. 161-186). Madison, WI: Soil Science Society of America.

Conant, R., Walsh, R., Walsh, M., Bell, C., \& Wallenstein, M. (2017). Effects of a microbial biostimulant, Mammoth P, on Cannabis sativa bud yield. Journal of Horticulture, 4(191), 23760354. 1000191.

D’andrea, P. (2002). Processo de compostagem líquida contínua-CLC e biofertilizante. Microbiol Indústria e Comércio LTDA BR/SP 2099.

de Oliveira Freire, J. L., Dias, T. J., Cavalcante, L. F., Fernandes, P. D., \& de Lima Neto, A. J. (2014). Rendimento quântico e trocas gasosas em maracujazeiro amarelo sob salinidade hídrica, biofertilização e cobertura morta. Revista Ciência Agronômica, 45(1), 8291.

De Zeeuw, R., Malingre, T. M., \& Merkus, F. (1972). Delta1Tetrahydrocannabinolic acid, an important component in the evaluation of cannabis products. Journal of Pharmacy and Pharmacology, 24(1), 1-6.

Detyniecki, K., \& Hirsch, L. (2015). Marijuana use in epilepsy: The myth and the reality. Current Neurology and Neuroscience Reports, 15(10), 65. https://doi.org/10.1007/s11910-015-0586-5

du Jardin, P. (2012). The science of plant biostimulants: A bibliographic analysis. Ad hoc study report. European Commission DG ENTR.

Eisenstein, M. (2015). Medical marijuana: Showdown at the cannabis corral. Nature, 525, S15. https://doi.org/10.1038/525S15a

El-Ghamry, A. M., El-Hai, K. A., \& Ghoneem, K. M. (2009). Amino and humic acids promote growth, yield and disease resistance of faba bean cultivated in clayey soil. Austrailian Journal of Basic Applied Science, 3(2), 731-739.
Ferrini, F., \& Nicese, F. (2002). Response of English oak (Quercus robur L.) trees to biostimulants application in the urban environment. Journal of Arboriculture, 28(2), 70-75.

Fike, J. (2016). Industrial hemp: Renewed opportunities for an ancient crop. Critical Reviews in Plant Sciences, 35(5-6), 406-424. https://doi.org/10.1080/07352689.2016.1257842

Finnan, J., \& Styles, D. (2013). Hemp: A more sustainable annual energy crop for climate and energy policy. Energy Policy, 58, 152162. https://doi.org/10.1016/j.enpol.2013.02.046

García, A. C., Berbara, R. L. L., Farías, L. P., Izquierdo, F. G., Hernández, O. L., Campos, R. H., \& Castro, R. N. (2012). Humic acids of vermicompost as an ecological pathway to increase resistance of rice seedlings to water stress. African Journal of Biotechnology, 11(13), 3125-3134.

Gensemer, R. W., Dixon, D. G., \& Greenberg, B. M. (1999). Using chlorophyll a fluorescence to detect the onset of anthracene photoinduced toxicity in Lemna gibba, and the mitigating effects of a commercial humic acid. Limnology and Oceanography, 44, 878888.

Germida, J., \& Walley, F. (1996). Plant growth-promoting rhizobacteria alter rooting patterns and arbuscular mycorrhizal fungi colonization of field-grown spring wheat. Biology and Fertility of Soils, 23(2), 113-120.

Gorelick, J., \& Bernstein, N. (2014). Elicitation: An underutilized tool in the development of medicinal plants as a source of therapeutic secondary metabolites. In D. L. Sparks (Ed.), Advances in Agronomy (Vol. 124, pp. 201-230). New York: Academic Press.

Gryndler, M., Sudová, R., Püschel, D., Rydlová, J., Janoušková, M., \& Vosátka, M. (2008). Cultivation of high-biomass crops on coal mine spoil banks: Can microbial inoculation compensate for high doses of organic matter? Bioresource Technology, 99(14), 6391-6399.

Hagerty, S. L., Williams, S. L. Y., Mittal, V. A., \& Hutchison, K. E. (2015). The cannabis conundrum: Thinking outside the THC box. The Journal of Clinical Pharmacology, 55(8), 839-841. https://doi. org/10.1002/jcph.511

Hassanpanah, D. (2009). In vitro and in vivo screening of potato cultivars against water stress by polyethylene glycol and potassium humate. Biotechnology, 8(1), 132-137.

Holley, J. H., Hadley, K. W., \& Turner, C. E. (1975). Constituents of cannabis sativa L. XI: Cannabidiol and cannabichromene in samples of known geographical origin. Journal of Pharmaceutical Sciences, 64(5), 892-895. https://doi.org/10.1002/jps.2600640546

Huang, X. D., McConkey, B. J., Babu, T. S., \& Greenberg, B. M. (1997). Mechanisms of photoinduced toxicity of photomodified anthracene to plants: Inhibition of photosynthesis in the aquatic higher plant Lemna gibba (duckweed). Environmental Toxicology and Chemistry: An International Journal, 16(8), 1707-1715.

Ievinsh, G., Vikmane, M., Kirse, A., \& Karlsons, A. (2017). Effect of vermicompost extract and vermicompost-derived humic acids on seed germination and seedling growth of hemp. Proceedings of the Latvian Academy of Sciences. Section B. Natural, Exact, and Applied Sciences, 71(4), 286. https://doi.org/10.1515/prolas-2017-0048

Iványi, I. (2011). Relationship between leaf nutrient concentration and the yield of fibre hemp (Cannabis sativa L.). Research Journal of Agricultural Science, 43(3), 70-76.

Jaleel, C. A., Manivannan, P., Wahid, A., Farooq, M., Al-Juburi, H. J., Somasundaram, R., \& Panneerselvam, R. (2009). Drought stress in plants: A review on morphological characteristics and pigments 
composition. International Journal of Agriculture \& Biology, 11(1), 100-105.

Jat, R., \& Ahlawat, I. (2006). Direct and residual effect of vermicompost, biofertilizers and phosphorus on soil nutrient dynamics and productivity of chickpea-fodder maize sequence. Journal of Sustainable Agriculture, 28(1), 41-54.

Jensen, B., Chen, J., Furnish, T., \& Wallace, M. (2015). Medical marijuana and chronic pain: A review of basic science and clinical evidence. Current Pain and Headache Reports, 19(10), 50. https://doi.org/10.1007/s11916-015-0524-x

Kelting, M. P. (1997). Effects of soil amendments and biostimulants on the post-transplant growth of landscape trees. Thesis. Virginia Tech. Retrieved from http://hdl.handle.net/10919/36957

Kirkham, M. B. (2014). Principles of soil and plant water relations. New York: Academic Press.

Kriese, U., Schumann, E., Weber, W. E., Beyer, M., Brühl, L., \& Matthäus, B. (2004). Oil content, tocopherol composition and fatty acid patterns of the seeds of 51 Cannabis sativa L. genotypes. Euphytica, 137(3), 339-351. https://doi.org/10.1023/b:EUph. 0000040473.23941 .76

Liddycoat, S. M., Greenberg, B. M., \& Wolyn, D. J. (2009). The effect of plant growth-promoting rhizobacteria on asparagus seedlings and germinating seeds subjected to water stress under greenhouse conditions. Canadian Journal of Microbiology, 55(4), 388-394.

Lotfi, R., Gharavi-Kouchebagh, P., \& Khoshvaghti, H. (2015). Biochemical and physiological responses of Brassica napus plants to humic acid under water stress. Russian Journal of Plant Physiology, 62(4), 480-486.

Mahlberg, P. G., \& Kim, E. S. (2004). Accumulation of cannabinoids in glandular trichomes of Cannabis (Cannabaceae). Journal of Industrial Hemp, 9(1), 15-36.

Mishchenko, S., Mokher, J., Laiko, I., Burbulis, N., Kyrychenko, H., \& Dudukova, S. (2017). Phenological growth stages of hemp (Cannabis sativa L.): Codification and description according to the BBCH scale. Žemès ūkio mokslai, 24(2).

Murari, G., Puccini, A., Sanctis, R. d., \& Lombardi, S. (1983). Influence of environmental conditions on tetrahydrocannabinol (Delta ('9) TCH) in different cultivars on Cannabis sativa L. Fitoterapia (Italy), 1983.

Noodén, L. D., \& Leopold, A. C. (2012). Senescence and aging in plants. New York: Academic Press Inc. and Elsevier.

Olivares, F. L., Aguiar, N. O., Rosa, R. C. C., \& Canellas, L. P. (2015). Substrate biofortification in combination with foliar sprays of plant growth promoting bacteria and humic substances boosts production of organic tomatoes. Scientia Horticulturae, 183, 100108.

Oxborough, K., \& Baker, N. R. (1997). Resolving chlorophyll a fluorescence images of photosynthetic efficiency into photochemical and non-photochemical components-calculation of qP and Fv/Fm without measuring Fo. Photosynthesis Research, 54(2), 135142.

Pagnani, G., Pellegrini, M., Galieni, A., D’Egidio, S., Matteucci, F., Ricci, A., ... Pisante, M. (2018). Plant growth-promoting rhizobacteria (PGPR) in Cannabis sativa 'Finola' cultivation: An alternative fertilization strategy to improve plant growth and quality characteristics. Industrial Crops and Products, 123, 75-83.

Paris, M., Boucher, F., \& Cosson, L. (1975). The constituents of Cannabis sativa pollen. Economic Botany, 29(3), 245-253.
Pereg, L., de-Bashan, L. E., \& Bashan, Y. (2016). Assessment of affinity and specificity of Azospirillum for plants. Plant and Soil, 399(1), 389-414. https://doi.org/10.1007/s11104-015-2778-9

Requena, N., Jimenez, I., Toro, M., \& Barea, J. (1997). Interactions between plant-growth-promoting rhizobacteria (PGPR), arbuscular mycorrhizal fungi and Rhizobium spp. in the rhizosphere of Anthyllis cytisoides, a model legume for revegetation in mediterranean semi-arid ecosystems. The New Phytologist, 136(4), 667-677.

Richmond, A. (1999). Physiological principles and modes of cultivation in mass production of photoautotrophic microalgae. Taylor \& Francis (Chemicals from Microalgae), 1999, 353-386.

Rosenberg, E. C., Tsien, R. W., Whalley, B. J., \& Devinsky, O. (2015). Cannabinoids and epilepsy. Neurotherapeutics, 12(4), 747768. https://doi.org/10.1007/s13311-015-0375-5

Ruiz-Sánchez, M., Aroca, R., Muñoz, Y., Polón, R., \& Ruiz-Lozano, J. M. (2010). The arbuscular mycorrhizal symbiosis enhances the photosynthetic efficiency and the antioxidative response of rice plants subjected to drought stress. Journal of Plant Physiology, 167(11), 862-869. https://doi.org/10.1016/j.jplph.2010.01.018

Ruiz-Lozano, J., \& Azcón, R. (1995). Hyphal contribution to water uptake in mycorrhizal plants as affected by the fungal species and water status. Physiologia Plantarum, 95(3), 472-478.

Russo, R. O., \& Berlyn, G. P. (1991). The use of organic biostimulants to help low input sustainable agriculture. Journal of Sustainable Agriculture, 1(2), 19-42.

Sausserde, R., \& Adamovics, A. (2013). Industrial hemp for biomass production. Journal of Agricultural Engineering, 2013, 44-45. https://doi.org/10.4081/jae.2013.365

Seleiman, M. F., Santanen, A., Kleemola, J., Stoddard, F. L., \& Mäkelä, P. S. A. (2013). Improved sustainability of feedstock production with sludge and interacting mycorrhiza. Chemosphere, 91(9), 12361242. https://doi.org/10.1016/j.chemosphere.2013.02.004

Shand, C. (2007). Plant nutrition for food security: A guide for integrated nutrient management. Experimental Agriculture, 43(1), 132132. https://doi.org/10.1017/S0014479706394537

Sharma, G. (1975). Altitudinal variation in leaf epidermal patterns of Cannabis sativa. Bulletin Torrey Botanical Club, 102, 199-200.

Shivprasad, S., Pogue, G. P., Lewandowski, D. J., Hidalgo, J., Donson, J., Grill, L. K., \& Dawson, W. O. (1999). Heterologous sequences greatly affect foreign gene expression in tobacco mosaic virusbased vectors. Virology, 255(2), 312-323.

Stearn, W. T. (1970). The cannabis plant: Botanical characteristics. The Botany and Chemistry of Cannabis, 1970, 1-10.

Tattini, M., Bertoni, P., Landi, A., \& Traversi, M. L. (1991). Effect of humic acids on growth and biomass partitioning of containergrown olive plants. Acta Horticulturae, 1991, 75-80. https://doi. org/10.17660/ActaHortic.1991.294.7

Turner, J. C., Hemphill, J. K., \& Mahlberg, P. G. (1978). Quantitative determination of cannabinoids in individual glandular trichomes of Cannabis sativa L. (Cannabaceae). American Journal of Botany, 65(10), 1103-1106.

Veres, S., Lévai, L., Marozsán, M., Gajdos, É., Bákonyi, N., \& Tóth, B. (2009). Changes of some chlorophyll-fluorescence parameters under biofertilization. Zbornik Radova 44. Hrvatski i 4 Medunarodni Simpozij Agronoma, Opatija, Hrvatska, 16-20 Veljače 2009, pp. 662-665.

Vessey, J. K. (2003). Plant growth promoting rhizobacteria as biofertilizers. Plant and Soil, 255(2), 571-586. 
Wang, K.-H., Radovich, T., Pant, A., \& Cheng, Z. (2014). Integration of cover crops and vermicompost tea for soil and plant health management in a short-term vegetable cropping system. Applied Soil Ecology, 82, 26-37. https://doi.org/10.1016/j.apsoil.2014.05. 003

Weisheit, R. A. (2011). Cannabis cultivation in the United States. World wide weed: Global trends in cannabis cultivation and its control, pp. 145-162.

Werf, H. v. d. (1994). Crop physiology of fibre hemp (Cannabis sativa L.). Van der Werf, S.l. Retrieved from http://edepot.wur.nl/ 202103

Werse, B. (2016). Legal issues for German-speaking cannabis growers. Results from an online survey. International Journal of Drug Policy, 28, 113-119. https://doi.org/10.1016/j.drugpo.2015.10. 007

Zhang, X., Ervin, E., \& Schmidt, R. (2003a). Physiological effects of liquid applications of a seaweed extract and a humic acid on creeping bentgrass. Journal of the American Society for Horticultural Science, 128(4), 492-496.
Zhang, X., Ervin, E., \& Schmidt, R. (2003b). Seaweed extract, humic acid, and propiconazole improve tall fescue sod heat tolerance and posttransplant quality. HortScience, 38(3), 440-443.

Zhang, X., \& Schmidt, R. (1999). Antioxidant response to harmonecontaining product in Kentucky bluegrass subjected to drought. Crop Science, 39(2), 545-551.

Zuardi, A. W. (2006). History of cannabis as a medicine: A review. Brazilian Journal of Psychiatry, 28(2), 153-157. https://doi.org/10. 1590/S1516-44462006000200015

How to cite this article: Da Cunha Leme Filho JF, Thomason WE, Evanylo GK, et al. Biochemical and physiological responses of Cannabis sativa to an Integrated Plant Nutrition System (IPNS). Agronomy Journal. 2020;112:5237-5248.

https://doi.org/10.1002/agj2.20400 